\title{
Piston Guide Device
}

National Cancer Institute

\section{Source}

National Cancer Institute. Piston Guide Device. NCI Thesaurus. Code C49975.

A device similar to a bushing but designed to reduce the linear friction between a piston and its cylinder. 